\title{
An Apology for the Scholarship of Teaching and Learning
}

\author{
Jacqueline M. Dewar, PhD \\ Professor, Department of Mathematics \\ Loyola Marymount University
}

This paper provides a defense of the scholarship of teaching and learning (SoTL). It first examines the roots of SoTL. It then offers examples of SoTL investigations that can be pursued in any discipline and places them within a taxonomy of SoTL questions. It suggests that SoTL might serve as a natural and organic response to the changing landscape and challenges of higher education in the $21^{\text {st }}$ century. The paper closes with resources and suggested entry points into this work for interested faculty and institutions.

The January 2008 issue of International Commons (Chick, 2008), the newsletter for the International Society for the Scholarship of Teaching and Learning, provides evidence that the scholarship of teaching and learning (SoTL) movement is undergoing some introspection. Articles question the role of the disciplines in the scholarship of teaching and learning (p. 1, 2, 10-11), state that there is no single national perspective on SoTL in the United States (p. 4), and offer a draft statement by the leaders of the CASTL (Carnegie Academy of the Scholarship of Teaching and Learning) team on the impact of SoTL intended "as a starting point for a discussion that will lead us to a better understanding of the nature of SoTL impact" (p. 13). The appearance of these introspective pieces written by leaders of the SoTL movement suggests there might be value in constructing a defense of SoTL at this time. This paper presents such an "apology" by first examining the roots of SoTL and making distinctions among closely related topics. To clarify and illuminate the scholarly work known as SoTL, it supplies examples and applications of SoTL investigations in a variety of disciplines, casts them in a way that allows consideration by scholars from multiple fields, and situates them within a taxonomy of SoTL questions. The paper then describes the ways in which SoTL addresses many challenges facing higher education in the $21^{\text {st }}$ century. It concludes by suggesting resources and entry points for faculty and institutions interested in pursuing the scholarship of teaching and learning.

\section{Describing the Scholarship of Teaching and Learning}

The scholarship of teaching and learning (SoTL) has engendered many descriptions since Ernest Boyer (1990) introduced the phrase "scholarship of teaching" into the vocabulary of higher education in his book, Scholarship Reconsidered. In it, he proposed that colleges and universities needed a fresh vision of scholarship in order to tap the full range of faculty talents and to encourage vital connections between academic institutions and their local communities. He labeled and described four types of scholarship: discovery, application, integration and teaching, and he discussed characteristics of SoTL but did not define it. As President of the Carnegie Foundation for the Advancement of Teaching, Boyer brought national and international attention to SoTL, but others had discussed similar concepts before his book. For example, Cross (1986) argued that faculty across the nation should undertake research on teaching and learning in their own college classrooms in order to discover more effective teaching methods and establish a body of knowledge about college teaching that would maximize learning. Later, the next Carnegie President Lee Shulman and Vice President Pat Hutchings would state that the scholarship of teaching is integrating the experience of teaching with the scholarship of research (Hutchings \& Shulman, 1999).

More recently, Carnegie Senior Scholars Mary Huber and Pat Hutchings (2005) have "come to embrace a capacious view of the topic, wanting to draw this movement in the broadest possible terms" (p. 4). They see SoTL ranging from

InSight: A Journal of Scholarly Teaching 
modest investigations that document the teaching and learning in a single classroom, the results of which are shared with others, to studies with elaborate research designs that go well beyond a single classroom. For the purposes of this article, we define SoTL as the intellectual work that faculty do when they use their disciplinary knowledge to investigate a question about their students' learning, submit their findings to peer review, and make them public for others in the academy to build upon.

One of the many sources of confusion about this work and its value to higher education is the need to draw distinctions among "good

Scholarly teachers and their teaching must be informed not only by the latest developments in their field but also by research about instructional design and methods of assessing student learning and teaching," "scholarly teaching" and the "scholarship of teaching and learning." Ronald Smith (2001) writes that good (or better) teaching is defined and measured by the quality of student learning, while scholarly teaching requires something more. Scholarly teachers and their teaching must be informed not only by the latest developments in their field but also by research about instructional design and methods of assessing student learning and teaching in their field. Based on this research, scholarly teachers make choices about instruction and assessment for their classes and their students. Practitioners of the scholarship of teaching and learning contribute to this knowledge base by carrying out research on teaching and learning. This SoTL research can involve aspects of discovery, application and integration and is intended to improve practice within and beyond the investigators' own classrooms.

Another distinction worth making is how SoTL differs from pedagogical strands within individual disciplines. Frequently, major disciplinary conferences will host some sessions that would best be described as "teaching tips" and others that would be identified as educational or pedagogical research within the discipline. It is important to understand how these different strands relate to the scholarship of teaching and learning. Figure 1 provides one model for this relationship by placing the labels "teaching tips," "scholarship of teaching and learning," and "disciplinary education research" at the three vertices of an equilateral triangle. Teaching tips describes a teaching method or innovation that the instructor and students 'liked.' As one begins to systematically gather evidence from students about what (if any) cognitive or affective effect the method had on their learning, one is moving toward scholarship of teaching and learning. The third vertex of the triangle, disciplinary educational research (for example, physics education research or research on undergraduate mathematics education), matches up quite well with Boyer's scholarship of discovery. In this type of educational research within a discipline, research methodologies, theoretical frameworks, empirical studies, reproducible results, control groups, and so on command greater importance than is typically found in SoTL. Of course, rarely does a single piece of scholarship sit exactly at one vertex. Huber and Hutchings' view is that there can be a big tent whose purpose is to improve the teaching and learning as a whole (2005).

Figure 1: Situating SoTL Work within a Disciplinary Pedagogical Spectrum

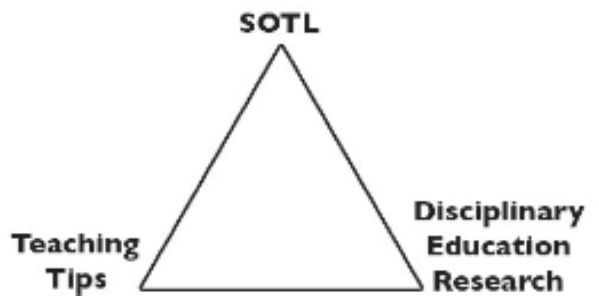




\section{Examples of SoTL}

In SoTL, just as in any discipline, studying examples can greatly assist understanding. Scholars from ten different fields provide examples and describe the evolution of SoTL work in their respective fields in Huber and Morreale (2002). Their essays testify to both disciplinary differences and shared spaces in this work. Here is a collection of SoTL questions adapted from recent SoTL work in the field of mathematics (Bennett and Dewar, 2007; Dewar, 2008; Zachariah, Larson and Dewar, 2006) and reframed in such a way as to be approachable in virtually any discipline.

1. Questions about the signature method for determining truth or generating new knowledge in a discipline:

(a) How does ---fill in a discipline--- majors' understanding of ---signature method within a discipline--- evolve as they move through the curriculum?

(b) What courses or other learning experiences have the greatest effect on the development of their understanding of ---signature method within a discipline---?

More specifically, in mathematics, these questions become: As mathematics majors move through the curriculum, how does their understanding of proof evolve and which courses or other learning experiences contribute the most to their understanding of proof? In sociology, faculty would ask: How does sociology majors' understanding of the sociological imagination evolve as students move through the curriculum and what exerts the greatest influence on their development of understanding? In science, the question would be about student understanding of the scientific method.

2. Questions about defining the discipline itself:

(a) How do K-12 future teachers describe ---fill in a discipline---?

(b) How does their description compare to that of experts in the field?

(c) How much can a single course shift future teachers' views toward that held by experts and what in that course is responsible for the shift?

For example, one might inquire: What do future teachers think that history or mathematics is really about? Do they think that history is just learning the dates and details of past events or that mathematics is simply the study of numbers and their applications? How do these views compare to those held by faculty in the history or mathematics departments? Can a single course encourage students to adopt a more expert perspective?

3. Questions about connecting the discipline to real life:

(a) How does the addition of a civic engagement component to a ---fill in the discipline--- course influence student learning and attitudes towards ---fill in the discipline---?

As an example: What might happen if semester-long group projects on local community or campus issues like parking, student health center use, or financial planning after graduation were incorporated into a general education mathematics course? Is it possible that students would learn more or make new connections between the classroom and daily life or change their attitudes about the value of learning mathematics?

The above questions can be categorized according to what has developed into a taxonomy of SoTL questions:

- What-is? (These questions examine a current situation in an attempt to describe it fully, as \#1(a), 2(a), and 2(b) above do.)

- What-works? (These questions seek evidence for the effectiveness of a particular method or approach, as \#1(b) and 2(c) do.)

- What-could-be? (These questions provide a vision of what is possible, such as \#3(a).) 
In Opening Lines, Hutchings (2000) describes these three and a fourth type of investigation, one that leads to a new framework or conceptual model for understanding some aspect of teaching and learning. It is common for SoTL investigations to begin with "What-works" questions but in the process of reframing the questions to make them more researchable they morph into "What-is" questions. Sometimes SoTL projects involve several different types of questions simultaneously.

SoTL work is rarely considered in the same light as traditional disciplinary research unless one's field happens to recognize disciplinary pedagogical research such as physics education within the field of physics. As a result, the question naturally arises: By what standards should SoTL work be evaluated? Glassick, Huber, and Maeroff (1997) provided the first significant response to this concern. In Scholarship Assessed, they assured the academy that SoTL is judged by the same criteria as the traditional scholarship of discovery: clear goals, adequate preparation, appropriate methods, significant results, effective presentation, and reflective critique and suggested a series of questions to further explicate each criterion (Glassick, et al, 1997, p.36, Exhibit 2.1).

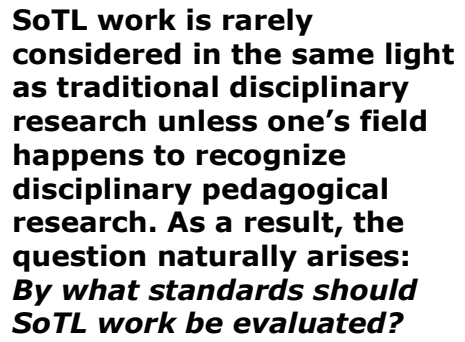

SoTL work is rarely considered in the same light as traditional disciplinary research unless one's field happens to recognize disciplinary pedagogical research. As a result, the question naturally arises: By what standards should SoTL work be evaluated?

\section{Why Bother with SoTL?}

How much colleagues, departments and institutions "count" SoTL varies widely. SoTL is often considered to be a nice "add-on" to a record of traditional disciplinary research, especially when the SoTL work is seen as cross- or interdisciplinary. So why should a faculty member or an institution be interested in pursuing or supporting SoTL? Because the landscape of higher education has changed tremendously in the last several decades a number of reasons can be offered. Increasingly student bodies are more diverse, with ever-larger percentages of high school students entering college. In 1960 only $45 \%$ of students completing high school entered college within twelve months as opposed to $66 \%$ in 2006 (National Center for Education Statistics, 2007). This is but one factor contributing to the continually transforming generational divide evidenced in the Beloit College Mindset List (2007). Technology offers many new options for instruction and neuroscience has made new discoveries about the physical basis of learning (Leamnson, 1999). Each of these advances holds implications for teaching that present numerous opportunities for SoTL investigations.

SoTL also offers faculty a means other than student or peer evaluations to document their teaching and their students' learning for merit, tenure and promotion applications. Increasing calls for assessment and greater accountability in higher education present institutions and faculty with yet another challenge. By asking and answering SoTL questions like those listed above, faculty can find out how well they are teaching, how well their students are learning, and they obtain insights for making improvements. Suddenly SoTL begins to sound a lot like assessment. This is because, although they are distinct, SoTL and assessment possess great synergy. Faculty who do SoTL work are likely to develop a mindset that is positively disposed toward assessment. A student's B+ grade in calculus, typically an amalgamation of homework, quizzes, tests and/or papers, would by itself never be sufficient to answer a What-is, What-works, or What-could-be SoTL question.

So it is natural for a SoTL practitioner to conclude that grades alone do not tell if or how well a student mastered a desired learning outcome. SoTL questions often probe deeply into learning outcomes. For example, demonstrating an understanding of and being able to use the signature method for generating new 
results in a given discipline (such as proof in mathematics) would be an obvious learning outcome for a degree program in that discipline. Moreover, faculty who asked and attempted to answer SoTL questions have had to gather evidence that goes beyond grades on assignments and tests and they have done so systematically. As a result, they have very likely developed a skill-set that would be useful in assessment. Some of the course or department level SoTL investigations can even scale up to the institutional level. Finally, SoTL can strengthen faculty development efforts and lead to involvement either individually or institutionally in national or international higher education initiatives. All in all, it seems that SoTL offers great promise in addressing many of the challenges facing higher education and can directly benefit faculty practitioners and their students.

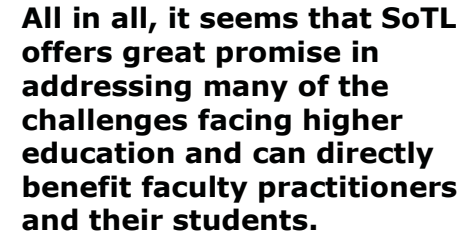

All in all, it seems that SoTL in education and can directly and their students.

\section{Additional Resources for Pursuing SOTL}

As a result of its development into an international movement, the number of resources available to support the scholarship of teaching and learning continues to grow. The Carnegie Foundation for the Advancement of Teaching (http://www.carnegiefoundation.org) and the International Society for the Scholarship of Teaching and Learning (http://www.issotl.org) provide support and examples of this work. For faculty interested in pursuing this scholarly endeavor, McKinney (2007) can serve as a very useful and practical guide. Since 2002 the Carnegie Academy for the Scholarship of Teaching and Learning (CASTL) Summer Institute has been providing mentoring for SoTL scholars under the auspices of the Carnegie Foundation's CASTL Leadership Initiative (www2.creighton.edu/castl2008). Colleges and universities prepared to make a commitment to the scholarship of teaching and learning by exploring the place of such work in their settings can find recognition and support by joining the Carnegie CASTL Affiliates program.

\section{Conclusion}

This "apology" for the scholarship of teaching and learning has examined the initiation of the movement and sought to distinguish it from closely related topics and pedagogical concerns within individual disciplines. It offered examples of SoTL investigations that could be pursued in virtually any discipline and placed them within a taxonomy of SoTL questions. It reprised the question of how SoTL is valued and evaluated. Finally, it explored the relevance of SoTL to higher education in the $21^{\text {st }}$ century, offered several resources and suggested entry points into this work for interested faculty and institutions.

\section{References}

Beloit College Mindset List. (2007). Retrieved October 4, 2007, from http://www.beloit.edu/ pubaff/mind set/
Bennett, C. \& Dewar J. (2007).

Developing and applying a taxonomy for mathematical knowledgeexpertise. Electronic proceedings for the tenth special interest group of the Mathematical Association of America on Research in Undergraduate Mathematics Education Conference on Research in Undergraduate Mathematics Education. Available from http://www.rume.org/crume2007/epr oc.html 
Boyer, E. (1990). Scholarship reconsidered: Priorities of the professoriate. Princeton, NJ: The Carnegie Foundation for the Advancement of Teaching.

Chick, N. (Ed.). (2008, January). The International Commons, 3(1).

Available from

www.issotl.org/newsletter.html

Cross, K. (1986). A proposal to improve teaching or what 'taking teaching seriously' should mean. AAHE Bulletin, 39(1), 9-14.

Dewar, J. (2008). What is mathematics: Student and faculty views. Electronic Proceedings for the Eleventh Special Interest Group of the Mathematical Association of America on Research in Undergraduate Mathematics Education Conference on Research in Undergraduate Mathematics Education. Available from http://cresmet.asu.edu/crume2008/P roceedings/Proceedings.html

Glassick, C. E., Huber, M. T. \& Maeroff, G. I. (1997). Scholarship assessed: Evaluation of the professoriate. San Francisco: JosseyBass.

Huber, M. T. \& Hutchings, P. (2005). The advancement of learning: Building the teaching commons. San Francisco: Jossey-Bass.

Huber, M. T. \& Morreale, S. (2002). Disciplinary styles in the scholarship of teaching and learning: Exploring common ground. Sterling, Virginia: Stylus.
Hutchings, P. (2000). Opening lines: Approaches to the scholarship of teaching and learning. Menlo Park, CA: Carnegie Foundation.

Hutchings, P. \& Shulman, L.S. (1999). The scholarship of teaching: New elaborations, new developments. Change, 31(5), 10-15.

Leamnson, R. (1999). Thinking about teaching and learning: Developing habits of learning with first year college and university students. Sterling, Virginia: Stylus.

McKinney, K. (2007). Enhancing learning through the scholarship of teaching and learning. Bolton, MA: Anker Publishing.

National Center for Education Statistics. (August, 2007). Retrieved April 2, 2008 from http://nces.ed.gov/programs/digest/ d07/tables/dt07_191.asp

Smith, R. (2001). Formative evaluation and the scholarship of teaching and learning. In C. Knapper \& P. Cranton (Eds.) Fresh approaches to the evaluation of teaching. New Directions for Teaching and Learning, no. 88. San Francisco: Jossey-Bass.

Zachariah, T., Larson, S. \& Dewar, J. (2006). An emerging model: Quantitative literacy through community-based group projects. Retrieved April 4, 2008 from http://www.sencer.net/Resources/pd fs/Models_Print_Web_2006/Quantitat ive_Literacy_Model.pdf

Jacqueline Dewar, PhD, has taught mathematics for 35 years at Loyola Marymount University and been involved in faculty development for two years. She was a 20034 Carnegie scholar and received the Mathematical Association of America's Deborah and Franklin Tepper Haimo Award for Distinguished College or University Teaching of Mathematics in 2006. 